\title{
Discussion on Students' Awareness of Volunteer Services
}

\author{
Deng Zhang \\ Northwestern Polytechnical University \\ Xi'an, China 710072
}

\begin{abstract}
Voluntary service cause, as a social governance mode in which people participate effectively, plays an important role in the development of socialism with Chinese characteristics in the new era. People's voluntary service awareness determines the behaviors of voluntary services fundamentally, which is the internal driving force of the development of voluntary services. College students are the new force of voluntary services, and cultivating their awareness of voluntary services embodies the requirements of the times for the common development of people and the society in the new period, the theoretical requirements for the integration of ideological and political education and the spirit of volunteerism, as well as the realistic requirements for the reform of ideological and political education and the practice of the core values of socialism.
\end{abstract}

Keywords—volunteer service awareness; cultivation; value

\section{INTRODUCTION}

Voluntary services originated from charitable services of western religious groups in the early 19th century, and up to this day, after more than two centuries of development, voluntary services become further legalized, universal and community-based in the west, as well as important ways to ease social contradictions, promote social harmony and spread civilization. The spirit of 'humanitarianism' as the core value and 'altruism' as the main principle of behavior and "humanistic public welfare" with the realization of the general happiness of society as the main goal reflected by the Christian spirit of public welfare and charity and the autonomy of villages and towns and the spirit of villages and towns have gradually become the core values for promoting the development of western volunteerism. Along with the development of three stages of budding, expansion, and standardization of western volunteer services, the cultivation system of volunteer service awareness has penetrated into all aspects of the social field, cultivated the awareness of citizens' volunteer services in a silent manner, and volunteer service activities almost become widely known in many countries, and citizen participation in voluntary service activities has already been a self-conscious action.

"After the spirit of volunteerism rooted in people's hearts is aroused, it may be vague, uncertain and fragile, and unable to offer real guidance to actions"[1], therefore, it is required to, based on the theories of ideological and political education, integrate the value concepts of volunteerism into the content of ideological and political education, and carry out the work of cultivating the awareness of voluntary services in an all-round and planned manner step by step from the four aspects of family, school, society and individual, gradually cultivate and enhance people's cognition, psychology, attitude and sense of participation of voluntary services, lead people to actually participate in voluntary service activities, gradually comprehend the connotations of volunteerism in the concrete practice of unity of knowledge and practice, take this as the goal to strengthen the awareness of active participation and the spirit of dedication, and promote voluntary service awareness to develop towards in a clarified, definite and firm direction.

\section{ANALYSIS OF RELATED CONCEPTS}

\section{A. Volunteer Services}

Under the background of globalization, with the improvement of citizens' quality, voluntary services have become a national craze, and voluntary service is also regarded as an important way for social members to participate in social operations and improve public living space. From a broad perspective, as long as the behaviors that contribute one's own time, energy or financial resources consciously, voluntarily and without compensation and serve the social benefit on this basis to promote social progress and development can be identified as voluntary services. In a narrow sense, voluntary services refer specifically to specialized services provided by volunteer organizations registered by legal institutions through certain procedures, and also include voluntary services carried out by registered volunteers themselves pursuant to relevant regulations.

\section{B. Volunteerism}

Volunteerism has different manifestations in the language expressions and connotations of various major nationalities due to the differences in political cultures among Western countries, and from an official point of view, UN Volunteer has defined volunteerism in its articles of association as "a kind of voluntary spirit of participating in human development, promoting social progress and improving the spirit of community work not for the sake of remuneration or income"[2]. In the definition of volunteerism, Ding Yuanzhu and Jiang Xunqing believe that "volunteerism is a kind of voluntary spirit of participating in human development, promoting social progress and 
improving the spirit of community work not for the sake of remuneration or income"[3]. China's consensus on the connotations of volunteerism comes from Comrade Jiang Zemin's summary of the content of volunteerism in the important instructions of Chinese young volunteers in 2001: dedication, fraternity, mutual aid and progress. In the reply to "Benyu Volunteer Service Team", General Secretary Xi Jinping further emphasized and reiterated "carrying forward the voluntary spirits of dedication, fraternity, mutual aid and progress" in the hope that they could "persist in walking with the motherland and contributing to the people, and make new and greater contributions to the realization of the Chinese dream with the dreams of youth and practical actions." [4]

\section{Voluntary Service Awareness}

Without considering external conditions, people's voluntary service awareness fundamentally decides their voluntary service behaviors, which is the internal driving force for the development of voluntary services. Therefore, the cultivation of voluntary service awareness is not merely the primary task for the development of voluntary service cause, but also an important path for ideological and political education to spread mainstream ideology in educational sense. However, the academic community mainly concentrates on volunteerism as the research content, and at present, there are few studies that clearly define voluntary service awareness so that the concepts of "volunteerism" and "voluntary service awareness" are vague and often mixed in use. Thus, defining the concept of voluntary service awareness will contribute to enriching the research results in the field of voluntary services. According to the definition of "voluntary service awareness" given by Chen Shaojun from Central South Social Research Institute: "voluntary service awareness is people's self-awareness to participate in voluntary services based on their own basic values and concepts on the basis of understanding volunteer services and voluntary service rules, and it is ultimately reflected in behaviors conducive to social development". Combining ideological and political education with the contemporary context of socialist thoughts with Chinese characteristics in the new era, this paper views that the concept of "voluntary service awareness" can be defined as follows: under the action of external factors and internal factors, people have gradually formed their cognition, psychology and attitude towards voluntary services and their self-awareness of participating in voluntary services according to their own values in social life. The development is a dynamic and nurturing process, and the ultimate goal of cultivating voluntary service awareness is to form a lifelong value orientation under the guidance of ideological and political education that takes serving the people and contributing to society as behavioral motives, and actively, voluntarily participates in voluntary service activities, strives for the realization of socialist modernization and the great rejuvenation of the Chinese nation.

\section{TIMES VALUE}

\section{A. The Need for the Development of Socialism with Chinese Characteristics in the New Era}

In October 2008, "Opinions on Carrying out In-depth Voluntary Service Activities" issued by the Central Guiding Committee for the Construction of Spiritual Civilization clearly stated, "young people are the new force of voluntary services, and schools are the main front for carrying out voluntary service education. Volunteer spirit should be regarded as an important content of ideological and moral construction of minors and ideological and political education of college students, and incorporated into the school's education and teaching, reflected in classroom teaching, extracurricular activities and social practice so as to continuously enhance the voluntary service awareness of the vast majority of teenagers." Since the 18th National Congress, voluntary service organizations, as important participants in social governance, have played a vital role in stimulating social vitality, responding to social needs, innovating social governance and improving people's wellbeing, etc. General Secretary Xi Jinping spoke highly of the cause of young volunteers in his reply and message to the group of young volunteers, pointing out that "the cause of young volunteers in China is a pioneering undertaking of the Communist Youth League led by our Party to innovate the work field and serve the needs of the society under the new historical conditions. The right direction for contemporary Chinese youth is for young volunteers to work together with the people, advance with the motherland, serve the people and dedicate the motherland." In 2014, Central Committee of Civilization issued "Opinions on Promoting the Institutionalization of Voluntary Services"; in 2015, the Ministry of Education issued the "Interim Measures for the Administration of Student Voluntary Services"; in March 2016, the National People's Congress passed the "Charity Law"; in June 2016, the Propaganda Department of the CPC Central Committee and other six ministries and commissions released "Opinions on Supporting and Developing Voluntary Service Organizations"; in January 2017, the "13th Fiveyear Plan" for the Development of the National Education Enterprise" proposed: "to build a working system of students' voluntary services, integrate voluntary services into social practice courses, organize students to carry out voluntary service activities and other thematic activities of social practice, establish records and files of students' voluntary services and include voluntary services into the evaluation of students' comprehensive quality." In September 2017, the State Council promulgated the "Voluntary Service Regulations", Article 29 of which stipulates that "schools, families and society should cultivate young people's voluntary service awareness and capacity", encouraging and regulating the cultivation of voluntary service awareness in the form of laws and regulations. General Secretary $\mathrm{Xi}$ Jinping clearly pointed out in the report of the 19th National Congress that "it is necessary to strengthen and improve ideological and political work,...... advance integrity construction and the institutionalization of voluntary services, and enhance the awareness of social responsibility, rules and dedication." From the establishment of social voluntary 
service system to its further improvement, to the in-depth development of voluntary service activities, and to the gradual establishment of institutionalized guarantee of voluntary services, all this fully exhibits that the Party and the State attach great importance to the development of college students' voluntary service activities and the cultivation of voluntary service awareness. The cultivation of college students' voluntary service awareness can effectively lead college students to practice socialist core values, influence and encourage more people to voluntarily devote themselves in voluntary services, and promote the development process of socialism with Chinese characteristics in the new era in the process of serving others and society.

\section{B. The Need for College Students to Realize Self- improvement and Development}

College students' voluntary services have the dual purposes of "serving the society" and "cultivating young people". In the cultivation of voluntary service awareness and the specific practice of voluntary services, college students not only deepen their understanding of society and enhanced their abilities, but also realize their selfimprovement and development. On the one hand, through the cultivation of voluntary service awareness, college students can deepen their scientific understanding of human nature, form a correct stand on the issue of the relationship between individuals and society, take pride in contributing to society and promote social progress as their mission, realize the significance and value of the interassociation between individuals in practice, give full play to and develop their own capabilities in the space provided by society, and further deeply comprehend that human nature is "the sum of all social relations". On the other hand, the cultivation of voluntary service awareness can help college students set up their life goals of serving the people and contributing to society. Whether a person can achieve free and all-round development depends mostly on whether he has set up correct aims in life, only when he has established serving the people and contributing to society as his fundamental aim in life will he strive to realize the all-round development of himself due to the rich and varied needs of society and realize the free development due to the mutual promotion between the individual and society. Thus, cultivating college students' voluntary service awareness to promote the development of volunteer service cause, deepening the understanding combined with the concrete social practice and realizing the unity of human development and social development are conducive to boost the development of college students in their physical and mental, moral, talent and personality and other aspect, as well as important approaches to realizing self-perfection and development of college students.

\section{The Need for the Discipline Development of Ideological and Political Education}

She Shuanghao considers: "Voluntary services have opened up a new field of ideological and political education research as a social activity that is widely carried out and deeply loved by the vast number of young people, an important entry point for the construction of socialist spiritual civilization under the new situation, an important component of the construction of socialist society, a normalized project for activities of learning from Lei Feng, and an important carrier for carrying forward and cultivating socialist core values, and a social activity that boasts extensive influence in social practice." Integrating the contents of voluntary services into the ideological and political education system of colleges and universities, giving play to the functions of ideological and political education in classroom teaching, extracurricular activities and social practice, and cultivating college students' voluntary service awareness will help to realize the change of ideological and political education concept from traditional subjective ideological and political education to intersubjective ideological and political education; the content transformation from traditional emphasis on grand narration, simple stress on the realization of social values and ignoring the individual existence of human beings to the combination of grand narration and ordinary narration, attaching importance to the combination of social values and individual values and highlighting the value exploration and significance discovery of individual life; the method transformation from focusing solely on macro view and cognitive education to the combination of macro and micro perspectives, the combination of cognitive and emotional education, valuing life moral education and carrying out education in close proximity to students' life. It expands and deepens the ideological and political education function for the cultivation of college students' voluntary service awareness and helps to boost the transformation and development of modern ideological and political education.

\section{THEORETICAL VALUE}

\section{A. Conducive to Enriching and Perfecting the Research of Voluntary Service Theories}

Most of the current academic researches on the theoretical system of voluntary services are conducted from the perspectives of voluntary spirit, voluntary behaviors, voluntary organizations and so on, ignoring the value embodiment of voluntary service awareness. From the perspective of the cultivation of voluntary service awareness, this paper interprets the connotations of voluntary service awareness, explores the formation mechanism of voluntary service awareness, and sums up the basic category of the cultivation of voluntary service awareness. The educational concept in combination with personal value and social value, theory and practice and emphasizing intersubjectivity, through the exertion of its ideological and political educational functions, can effectively promote the development of the voluntary service cause, realize the unity of the all-round development of human beings and social development in concrete social practice, advance the development process of the whole society, and help enrich the theoretical system of voluntary services. 


\section{B. Conducive to Expanding the Research Visual Field of Ideological and Political Education}

College students' voluntary services are an important platform and carrier for giving play to the functions of ideological and political education in colleges and universities. Based on the theories of ideological and political education, this paper explores the formation mechanism of voluntary service awareness, concludes the basic category of the cultivation of voluntary service awareness, gives play to the functions of ideological and political education in guiding thoughts, cultivating moral quality and regulating behavior habits, explores the practical path of cultivating college students' voluntary service awareness, and strengthens college students' voluntary service awareness. Moreover, practicing socialist core values in voluntary service activities consciously, voluntarily, effectively and for a long time is a new platform for colleges and universities to carry out "three outlooks" education and an effective approach to implement quality education and cultivate "youngsters with four virtues", an important way for contemporary college students to participate in social practice and expands the research visual field of ideological and political education.

\section{CONCLUSION}

\section{A. To Provide Countermeasures and Suggestions for the Implementation of Socialist Core Values}

College students are the basic subject to receive the cultivation of socialist core values. As the main front of cultivating socialist core values for college students, colleges and universities, based on the actual situations of schools and their own advantages and with cultivating and practicing socialist core values as the main line, promote the institutionalization and normalization of college students' voluntary service activities through the cultivation of college students' voluntary service awareness and effective participation in voluntary service activities, give play to the functions of ideological and political education in cultivating voluntary service awareness in combination with the educational value, spiritual value and social value of socialist core values, and actively explore the path of cultivating college students' socialist core values with voluntary service activities as the carrier. The cultivation of voluntary service awareness and participation in voluntary service activities can effectively verify, deepen and absorb the theoretical knowledge learned in the classroom, make college students gradually absorb the concepts of patriotism, dedication, honesty and friendliness in socialist core values through vivid practical experience, thus enhancing college students' profound understandings of abstract theoretical viewpoints in practice and further realizing their substantial identification with socialist core values. The results of the research will offer countermeasures and suggestions for college students to practice socialist core values.

\section{B. To Offer New Perspectives and Paths for Ideological and Political Education Practice in Colleges and Universities}

Nurturing the voluntary service awareness of college students can encourage them to participate in conscious, voluntary, effective and long-term voluntary service activities. In the integration of voluntary service activities and ideological and political education in institutions of higher learning, teaching in practice has played a positive role in enhancing the ideological and moral qualities of college students, enriching their spiritual and cultural life, and cultivating and practicing socialist core values. Therefore, in the process of ideological and political education reform, colleges and universities should fully understand the importance of ideological and political education function of college students' voluntary service activities, integrate the content of ideological and political education into voluntary service activities, strengthen the cultivation and guidance of college students' awareness of active participation in voluntary service activities, enhance their voluntary service awareness, perfect the operation mechanism and incentive supporting measures of their voluntary services so that college students can participate in voluntary service activities consciously, voluntarily, effectively and for a long time, thereby realizing the goals and requirements of ideological and political education.

Finally, the cultivation of college students' voluntary service awareness has initiated new research perspectives for boosting the development of voluntary services respectively from the value connotations embodied in the three levels of times, theory and reality, opened up new practical paths for practising socialist core values, and offered new development directions for the reform of ideological and political education in colleges and universities. In the process of guiding college students to participate in voluntary services consciously, voluntarily and free of charge, it inspires them to unify personal values and social values, and realize self-improvement and development in the process of achieving social development.

\section{REFERENCES}

[1] Beijing Volunteer Association. Volunteers, Are You Ready [M]. Beijing: China International Broadcasting Publishing House, 2006:127

[2] The United Nations Volunteers[EB/OL] http://www.unv.org/aboutUNV.html

[3] Ding Yuanzhu, Jiang Xunqing. Research on Volunteer Activities: Types, Evaluation and Management [M]. Tianjin: Tianjin Peoples Publishing House, 2001(1):2

[4] Xi Jinping. Xi Jinping's reply to "Benyu Volunteer Service Team" of Huazhong Agricultural University [N]. People's Daily, December 5, 2013 